\title{
Regulation of Property Tax in Tanzania: Legal and Administrative Challenges
}

\author{
By Hanifa T. MASSAWE*
}

\begin{abstract}
Property tax represents one among the most feasible, conventional, steady and progressive source of revenue. Nonetheless this form of tax has not received the attention it requires for effective contribution towards revenue generation in developing countries. The situation is however different in developed countries which have made concerted efforts to tap the potentials of property tax to achieve both fiscal and non-fiscal advantages for their communities. While taking this into account the current article conceptualizes the basic principles underlying property taxation as one among the forms of direct taxation while underscoring its value to revenue generation in general perspective. Thereafter specific analysis is made towards its practical regulation in a Tanzanian standpoint in terms of specific laws and regulatory machineries in the country. The analysis revolves around the effectiveness of the existing tax laws and regulatory machineries in ensuring optimum contribution by property tax to the country's revenue basket.

On the basis of doctrinal and empirical data it is revealed that despite its potential to contribute to revenue generation, property tax still faces a number of both legal and nonlegal challenges in its administration in the country. The legal challenges include poor legal definition on the concept of property, the flat rate structure on property tax, low deterrence effect of the penal sanctions. The non-legal challenges on the other hand include low registration of property owners and properties for identification purposes, irregular valuation process, low taxpayer education on property tax affecting voluntary property tax compliance and lacking resources for property tax administration by the respective regulatory machineries.

As a way to remedy the situation the paper provides a number of legal and non-legal intervention measures. The intervention measures take account of the importance of taxation for developing countries Tanzania inclusive, thus recommending solutions which reasonably combine regulatory convenience with equity and effectiveness. The recommendations are an output of theoretical data, empirical findings and specific international best practices on property taxation. The recommendations focus on legal clarification of the tax base, the method and basis for valuation and provision of required resources for enforcement of relevant laws on property taxation.
\end{abstract}

* Dr. Iur. Hanifa T. Massawe is a Lecturer at the Faculty of Law, Mzumbe University. 


\section{A. Introduction}

Taxes are monetary contributions disbursed by citizens of a specific community for the services rendered by their governments including but not limited to roads, electricity, security services and other infrastructures. Taxes in different jurisdictions exist in different forms depending on the tax structure of the specific jurisdiction supported by its specific tax policy embraced by the relevant laws thereto.

Property tax is a form of tax chargeable by government upon owners of real property within their jurisdiction on the basis of the real time value of such property. The Food and Agriculture Organization defines property tax as an annual tax imposed on real property usually by reference to an ad valorem tax base. ${ }^{1}$ Property tax is practically paid by the property owner on the basis of the value of the charged property. In most jurisdictions imposition of property tax is primarily on land and buildings whereas some countries extend its imposition on business and farm equipment and inventories.

Property tax carries the potential to serve as a viable source of revenue worldwide subject to optimum exploitation by respective authorities. Nevertheless this type of tax has not received full exploitation in most African countries Tanzania inclusive following a number of policy, legal and administration challenges. ${ }^{2}$ This article attempts to offer a synopsis of practical issues revolving around property tax administration in Tanzania while underscoring the legal and administrative challenges impairing its contribution to country's revenue basket.

\section{Methodology}

This paper adopts a socio-legal methodology in order to respond to specific issues pertaining to regulation of property tax in Tanzania. Socio-legal methodology is an approach used to analyze the law, legal phenomena and its relationship with the wider society in order to produce findings that were not determined in advance. Adoption of socio-legal methodology requires analysis of the law to investigate its adequacy in attending to a specific problem within the specific society. The socio-legal methodology method seeks to gain insight into a given problem from the perspective of the local population it focuses on in this case, Tanzania. ${ }^{3}$ Socio-legal methodology includes both theoretical and empirical data drawn from a socio-scientific point of view involving analysis directed towards the concerns, theories and informants of external perspectives with the aim of bringing insights that are not available in the context of a purely 'black law' or doctrinal approach. The purpose of adopting this method is to achieve an expository research which allows for flexibility of researcher to ex-

1 (FAO)(2002).

2 Konyimbih, T. M. 2002 Property Taxation in Tropical Africa: Policy and Strategy in three East African Countries, Journal of Property Tax Assessment and Administration, 7(1); 1-18.

3 Mack, N., Woodsong, C., MacQueen, K. M., Guest, G. \& Namey, E. (2005) Qualitative Research Methods: A Data Collectors Field Guide North Carolina: Family Health International. 
plore the causal link between ineffective property tax administration, property tax laws and regulations and the strength of the existing regulatory machineries.

\section{Historical background of Property Taxation}

Taxation of property in many Eastern and Southern African countries has a long history. ${ }^{4}$ This is evidenced by the introduction of the tax on landed properties and buildings in Tanzania (the then Tanganyika) through the Township Ordinance ${ }^{5}$ which introduced the "hut tax" to local property owners. The Ordinance was followed by the Municipalities Ordinance ${ }^{6}$ which aimed at developing property rating system on the assessed value of real property. The legislation endowed the Municipalities with authority to levy property tax at $10 \%$ on the capital value of all buildings situated therein save for those legally exempted. In 1952, the Local Government (Rating) Ordinance ${ }^{7}$ was enacted for the purpose of stretching the property tax base to include the value of unimproved site for those sites which were held on long-term leases. Therefore properties under long-term leases were subject to a tax on land and buildings while properties under short-term lease and customary laws were subject only to tax on buildings.

The post independence era came with socialist policies which led to structural change in the government thus an impact to property tax administration in Tanzania. For instance the nationalization agenda of 1967 rendered abolishment of all Local Government Authorities in the country consequently leading to abolition of property tax in the country. As a way of revamping administration of tax system on properties, the government enacted a number of legislations to cover the revenue gap which resulted from abolition of property tax. Among the newly enacted legislations was the Land Rent and Service Charge Act ${ }^{8}$ which was geared towards taxation of landed properties by combining land rent and service charge levied on land held under short- and long-term rights of occupancy. However this law was repealed by the Land $\mathrm{Act}^{9}$ which became the relevant legislation for charging land rent for use and occupation of land.

In the course of time the need to re-establish Local Government Authorities arose following deteriorating services and infrastructure thus its reestablishment in 1978. With the re-establishment of the Local Government Authorities property taxation returned to the fore through the Local Government Finance Act $^{10}$ hereafter LGFA which empowered local au-

4 Franzsen, R. and W.H.A Olima 2003, Property Tax Issues in Southern and East Africa: Lessons from South Africa and Kenya, Journal of Property Tax Assessment and Administration. 8(1): 118.

5 Cap. 101 of 1920.

6 Cap 105 of 1946.

7 Cap 317 of 1952.

8 Act No. 19 of 1974.

9 Act No. 4 of 1999.

10 Local Government Finance Act No. 9 of 1982. 
thorities to levy rates on landed properties. The LGFA was further supplemented by the Urban Authorities (Rating) Act ${ }^{11}$ hereafter UARA which authorizes urban and township to impose rates and buildings. The LGFA stands as a significant legal instrument which sets the rules on collection of property tax by the Local Government Authorities in line with which authorizes imposition of a flat rate property tax on landed properties. ${ }^{12}$ These rates are levied on buildings, adjusted by such factors as size, location, and use. The UARA on the other hand reintroduces an ad valorem property tax on buildings which could be levied in either urban and township authorities. ${ }^{13}$

Tanzania has implemented several major reforms on the administration of property tax in the country as stated above. In the administration process the country has seen adoption of changing models for property tax collection in different years. For instance in 2008, a new system for property tax collection was introduced in Dar es Salaam which entailed shifting the responsibility for administration and collection of property tax from the local government authorities to the Tanzania Revenue Authority (TRA), the national revenue collection agency. The aim of the shift was to increase the revenue collection which in turn failed to yield the expected result. Consequently, the Government reverted the responsibility to collect property tax to the LGA's in 2014. However the same did not last long as the duty to collect property tax was later re-assigned to TRA in July 2016 todate following the enactment of the Local Government Authorities (Rating) (Collection of Property Rates), Regulations. ${ }^{14}$

\section{B. Nature and Legal rules for Property Taxation}

Property tax is levied as a value-based taxation covering buildings within the taxing jurisdictions in actual occupation and improvements therein with the exclusion of undeveloped land. The legal duty to pay property tax is imposed on the property owner coupled with a corresponding liability upon failure to do the same. However the UARA ${ }^{15}$, LGFA ${ }^{16}$ and the Urban Authorities (Rating) Exemption from Liability of Rates Order ${ }^{17}$ afford tax exemptions to specific types of properties excluded from the tax liability. The exempted properties include those personally occupied by the President; properties used for public utilities or public worship, public libraries and museums, cemeteries and crematoria, civil and military

11 Cap 289 of 2010 as revised in 2019.

12 Section 13 and $15 \mathrm{c}$ of the LGFA.

13 The UARA is specifically applied only to urban and township councils. Thus, district and village councils are not legally authorized to levy a value-based property tax in Tanzania but may adopt the flat rate tax through local by-laws subject to central government approval under the Local Government Finance Act of 1982.

14 Government Notice No.1, Published on 03/1/2020.

15 Section 23(1) of the UARA.

16 Section 22 of the LGFA.

171997. 
aerodomes, sporting facilities, railway properties and any such property as the Minister responsible for Local Authorities shall prescribe. ${ }^{18}$ Responsibility for the various phases of property tax administration rests almost entirely upon respective government authorities. Administration involves the discovery or identification of the property to be taxed, its valuation, the application of the appropriate tax rate, and collection.

In order to effectively administer property tax through the value based taxation principle, the property in question must be valued properly. The valuation process is important in order to establish the corresponding ratable value on the basis of a proper rating structure followed by appropriate property tax collection and enforcement measures as elaborated hereunder:

\section{Valuation}

Important aspects in terms of property tax administration especially valuation, are a matter of judgment rather than of fact. Therefore in order to find clear judgment in terms of property taxation valuation is imperative as it forms the the basis of assessment of the property in question. Thus the determination of value for tax purposes should not be an incidental result rather a clearly planned activity aiming at producing specific value for which tax determination will base. Nonetheless valuation of properties for property taxation purpose has taken diverse approaches in a global perspective including the rental value, capital value, and market value. For instance the European countries have adopted the capital value approach as a mode of valuation for real property whereas the United States adopts the market value approach. The practice in Asian countries is fairly different as focus has been made towards adoption of annual rental value of the property as a determinant factor for property valuation and assessment.

Practically valuation is conducted by engaging physical visitation by a valuation surveyor to each property in order to determine the value of the building in question. In Tanzania the market value for buildings or improvements made to it forms the basis of property tax. ${ }^{19}$ This implies valuation of all buildings on the basis of cost replacement approach. The cost replacement approach entails attaching the real property value to the property in question in order to arrive at the base for which the property tax rate is applied. The application of the rate to the base enables ascertainment of the tax amount to be paid by the respective taxpayer.

UARA provides for the essentials of valuation process in Tanzania as a means to facilitate proper administration of property tax in the country. ${ }^{20}$ The UARA provides for declaration of rateable areas for valuation purpose in terms of the City Council, Municipal Coun-

18 Section 7 (a) -(m) of UARA read with regulation 16(1) of the Local Government Authorities (Rating) (Collection of Property Rates), Regulations.

19 Hidaya Kayuza (2006) Real Property Taxation in Tanzania: Reflections from Dar es salaam City, Utafiti, Vol 7, No. 1, p. 42.

20 Section 6 of UARA R.E of 2019. 
cil, Town Council or District Council. The law mandatorily acknowledges properties found in such areas as eligible for rating and taxation purposes. In order to facilitate identification of such properties the law necessitates preparation of a roll by the valuation surveyor which indicates a list of valuated properties in terms of names of property owners, location of the properties and level of improvement therein. ${ }^{21}$

\section{Rating}

In order to levy tax to the identified and valuated property proper rating structure is determined by relevant laws in a specific jurisdiction. ${ }^{22}$ Different tax jurisdictions apply different methods for calculating the rates for taxation of property. For instance some tax jurisdictions determine the property tax rate by multiplying the property tax rate by the current market value of the land in question followed by recalculation of the tax rate annually. Where the rates are prescribed by the respective authorities property owners are duty bound to adhere and pay accordingly. The UARA categorically stipulates the rating structure and specific rates for specific rateable areas within Tanzania. ${ }^{23}$ In the case of properties located in city council, municipal council and town council the law explicitly provides the rate of ten thousand Tanzanian Shillings $(10,000 /=$ Tshs. which is equivalent to 4.3 US Dollars $) .{ }^{24}$ Moreover the taxing rate for each storey in a storey building is set at fifty thousand Tanzania Shillings (50000/= Tshs. which is equivalent to 21.6 US Dollars) ${ }^{25}$ In a different perspective the law provides slightly different rates for properties found in District Councils as the same is set at ten thousand shillings $(10,000 /=$ Tshs. which is equivalent to 4.3 US Dollars) for ordinary building ${ }^{26}$ and twenty thousand shillings $(20,000 /=$ Tshs. which is equivalent to 8.6 US Dollars) for each storey in a storey building. ${ }^{27}$

\section{Property tax Collection and Enforcement}

An important component of a valuation-based property tax system is the need for a convenient and effective system of enforcement. While the valuation department is responsible for the valuation roll and issuance of the tax demand notices, the actual revenue collection and enforcement activities are administered through the relevant authority designated by the relevant law. As a way of enhancing compliance towards property tax payment the UARA

21 Section 8(2) (a)-(f) of UARA R.E of 2019.

22 Internal Revenue Service. "1.14.4 Personal Property Management.", available at https://www.irs.g ov/irm/part1/irm_01-014-00 accessed on September 2020.

23 Section $16(1)$ of the UARA.

24 Section 16(1)(a)(i) of the UARA.

25 Section 16(1)(a) (ii) of the UARA.

26 Section 16(b)(i) of the UARA.

27 Section 16(b)(ii) of the UARA. 
provides penalties ${ }^{28}$ and other remedies which may include restraint of goods, seizure of rents and profits, fines and interests on late payment exceeding the commercial rate, forfeiture of the property and imprisonment.

In 1999, the UARA was revised to increase the level of fines and penalties to more appropriate levels in line with current economic conditions. The same has been taken on board by the current amendments of the similar legislations which mandatorily requires the person who is duty bound to pay the rate to do so himself or through his representative. ${ }^{29}$ The law also provides for a warrant to be issued to seize the personal goods and the defaulter's chattels up to the value of the outstanding rates subject to failure to pay 60 days after issuance of the assessment. ${ }^{30}$ The Rating Authority may, at their discretion, recover any amount due by civil action without further notice or demand. ${ }^{31}$ In addition, all outstanding rates are to be a charge on the premise, having priority over other claims $\mathrm{s}^{32}$ and the law allows for the premise to be auctioned or sold in order to recover the outstanding rates. ${ }^{33}$ Moreover specific Local Government Authorities may enact By-Laws providing fines and penalties for failure to pay such tax. It is however important to note that enforcement of such laws leading to enhanced taxpayer compliance is highly dependent on optimum enforcement powers in case of non-payment by the taxpayers.

In the process of valuation, rating and collection of property tax a number of issues may ensue which may be a source of disputes between taxpayers and the regulatory authorities. As part of enforcement of property taxation such disputes should be dealt with by relevant dispute settlement machineries which possess relevant skilled and qualified personnel to adjudicate. It is further important to ensure that the adjudicating machineries are independent, easily accessible, speedy and with reasonable litigation costs. An effective tax dispute resolution system is vital for proper enforcement and administration of property taxation in the country.

\section{Practical/ Administrative and Legal Challenges on Property Taxation in Tanzania}

In order to properly effect property tax in any country laws and regulations should offer an enabling environment thereto. This is also the case for regulatory machineries responsible for administering property taxation in the country which are supposed to be designed in a manner which reflects readiness to enforce the law and properly administer property taxation. However this paper finds a number of challenges which beset the effort to administer

28 Section 47 of UARA.

29 Section 25 of UARA R.E of 2019.

30 Section 26(1) of UARA.

31 Section 26(2) of UARA.

32 Section 28 of UARA.

33 Section 29(1) of UARA. 
property taxation in the country to the extent of failing to achieve the desired results in terms of revenue generation to the country as discussed hereunder:

\section{Flat Rate Taxation vs Equity Principle}

The payment of tax at a flat rate stipulated under section 16(a) and (b) of UARA is applied for all properties in specific regions in Tanzania regardless of their size or location is considered counterproductive to the goals of taxation for the government. Attaching uniform rate of tax to the buildings unsupported by a corresponding value which would determine the proper rate to be paid for the same property highly affects revenue generation which is mainly the purpose of taxation in any jurisdiction. This practice goes against the equity principle of taxation which requires taxpayers to fairly contribute according to their economic station in life.

The flat rate system suppresses the owners of low valued property as it practically offers tax relief to those who own expensive properties/buildings. Despite the simplicity in administering the uniform flat rate property tax system it is pertinent to observe that it creates inequity perpetuated by vast differences in use, size, and location of buildings within the jurisdiction. Levying property tax was expected to take into account the real value of the said property. Therefore proper valuation of respective properties offering a corresponding tax rate would ensure that highly valued property building would generate high revenue to the government as compared to the lowly valued property.

\section{Limited Property Definition}

The definition of property establishing a tax base includes only buildings which are usually the subject of property taxation. The definition is self limiting thus restraining the taxation process only to buildings which is in itself counterproductive to the property tax collection process. The narrow definition of the property to include only buildings limits the potential tax base to property taxation as it fails to capture other things in the name of properties like farms, which could stretch the chances for revenue generation. For instance section 16 of the UARA describes the base of property taxation as an "ordinary building". However the law fails to clearly define an ordinary building or offer the legal parameters defining the same. The legal deficiency attracts practical generalizations which render failure to properly characterize and attach corresponding tax rate to specific buildings. This is attributed to the fact that what may seem as an ordinary building may relatively possess different attributes to different eyes.

\section{Poor/Low Registration of property owners \& properties}

In order to effectively collect tax, identification of the real subject of taxation is an imperative requirement in any tax jurisdiction. It is however revealed that the Tanzanian tax col- 
lection system has not exerted much effort in registration of buildings for the purpose of property tax collection. This argument is justified by the fact that there is no exact data on the eligible taxable buildings on the property tax roll in the country. Failure to ensure proper registration of properties eligible for property taxation impairs the government's tax collection efforts thus reduced revenue for development purposes. To alleviate this challenge it is suggested that the property tax system takes into account the pace of buildings construction in the country and facilitate registration of properties eligible for taxation.

Moreover it is important to note the remarkable government efforts to ensure citizens identification and registration through issuance of National Identification Cards from 2013 todate. It is anticipated that completion of the identification exercise would add significant value to identification of property owners thus ease of property valuation, tax collection and enforcement.

\section{Irregular Valuation Process}

Valuation process is a cornerstone to effective determination of the applicable rating to the property susceptible to taxation. It is therefore paramount before the respective authorities subject any property to taxation in the respective jurisdiction. However valuation of property in Tanzania is conducted on an irregular basis perpetuated by lacking time frame and properly organized system for this important exercise. One may associate the situation with few expertise and funding problems associated with the valuation exercise. Practice has seen property valuation being conducted by experts from the Ardhi University on behalf of the Local Government Authorities. However the valuation has not been carried out for the whole country in order to establish the market value of properties which may or may not be subject to taxation. Important as valuation would play a number of functions including identifying the properties for taxation purpose and also facilitate the rating as the market value of the property will facilitate the rating structure of the property in question thus a solution also to the non-adherence to the equity principle of taxation as presented under I. above.

\section{Low deterrence effect for failure to pay}

It is known that failure to pay tax is a criminal offence warranting a corresponding penalty as per the relevant laws. The amount of tax paid for property tax in Tanzania is set at 10000 Tshs. which is the equivalent of 4.3 US Dollars. This amount is considered too low and also contrary to the equity principle of taxation as the same amount is charged for every property regardless the value or location. The Tax Administration Act hereafter TAA prescribes interest for failure to pay tax in a statutory rate format. ${ }^{34}$ In case of failure to pay property tax or payment of the same out of time the TAA prescribes a penalty of $5 \%$ which is again

34 Section 76 of the Tax Administration Act No. 10 of 2015. 
considered low and thus non-deterrent thus fails to enhance compliance by taxpayers toward property tax.

The interest calculated at $5 \%$ of the standard amount charged for property tax an amount of $10000 /=$ Tshs. is calculated as $10,000 \times 5 \%=500$. For a criminal penalty to satisfy the requirement of its enactment and purpose of punishment it is expected that the same reduces manifestation of further commission of offences by other parties thus compliance towards property tax payment in this context. Nonetheless the interest rate of Tshs. 500 which is the equivalent of USD 0.22 in this context is considered significantly low to achieve a deterrent effect expected to enhance compliance by the taxpayers. The current state of affairs does not deter other taxpayers from ignoring to pay such tax. In this case one may associate the low compliance cost to the low compliance rate towards property tax in the country.

\section{Low coverage of landed properties in the property basket}

In order to ensure collection of property tax from the respective subjects identification of properties buildings eligible for such tax is imperative. However the extent of coverage of properties is still small signifying a lesser fraction of rateable properties for property taxation purposes. Low coverage of properties is a function of poor identification and registration of such properties by the relevant authorities in turn signifying low coordination by the respective LGA's. Improving coverage of landed properties for tax purposes signifies identification and determination of its physical existence its location, its size, its condition which in turn determines the rateable value in the context of property taxation as against the current practice adopting flat rate for property taxation as elaborated under B.II. above.

\section{Low taxpayer education on property taxation}

In order to secure revenue generation through property taxation taxpayer compliance is of paramount value. However the focus of tax compliance literature has been mainly on deterrence and tax morale as necessary features for achieving an increase in tax compliance ${ }^{35}$ while forgetting the concept of tax education and knowledge. Taxpayer education is necessary for assisting taxpayers to navigate through complex tax systems and participate effectively in tax payment. ${ }^{36}$ In order to achieve full compliance for property tax it is considered important for taxpayers to appreciate the tax base and the rationale behind its collection. It is quite unfortunate that taxpayer education for property tax has not been properly offered countrywide thus leading to low property tax payment morale by property owners in both urban and rural Tanzania. Consequently low property tax collection leads to its low contribution to revenue generation in the tax basket.

35 Giulia Mascagni and Fabrizio Santoro 2018 What is the Role of Taxpayer Education in Africa?p.6.

36 Ibid. 


\section{System for payment of property taxation not user-friendly for rural areas}

Convenience in tax payment is one among the factors which are expected to facilitate compliance for property taxation. However property tax payment procedures are not userfriendly as they require adoption of electronic payment system which may not be well achieved by most people especially those residing in rural areas. The procedure for payment of property tax has also not been user-friendly due to low understanding of the people and properties in rural areas on the issues pertaining to information and communication technology. Due to the fact that information and communication technology is still a challenge in terms of internet connectivity the same represents one among the grounds for failure to properly collect property tax in the country. Moreover there are some rural areas in which agents or banks facilitative to taxpayers do not exist in order to enable payment of property tax.

\section{Lack of Resources for property tax administration}

Proper collection of property tax is impractical where the resources necessary for the respective task are scarce. This has been the case for property taxation and collection in Tanzania where the same is faced with scarce resources necessary for its enhancement. It has been revealed that resources in the context of skilled personnel, funding, transportation for follow up on the specific areas is missing. Given the vastness of the country and the areas in which such tax should be collected the scarcity of the above resources poses difficulty in its administration. For instance lacking TRA offices within some districts in some Regions in the country poses difficulty in both identification of property owners and collection of property tax. Also the nature of property tax requires skilled and sufficient number of tax officers responsible for its administration. However the shift of the duty to administer property tax by the TRA from the LGA's has not taken into account the need to increase the human resource in that respect.

\section{Conclusion and Recommendations}

\section{Conclusion}

The foregoing discussion highlights on the importance of property taxation towards revenue generation in most jurisdictions Tanzania inclusive. The article further dwells on the historical background on regulation of property taxation in the country offering a clear picture on the important legal and practical features on taxation of properties in Tanzania. The author appreciates the basic standards necessary for regulating property taxation in the country in the context of proper valuation, rating, collection and enforcement. Such standards are accorded corresponding legal force through relevant laws. Nonetheless such laws have functionally revealed weaknesses in enhancing property tax collection followed by administrative challenges by the regulatory machineries. Synchronizing the gist of the discus- 
sion above it is pertinently observed that effective property tax performance is the subject of effective valuation, full coverage of property in the revenue basket, the appropriate tax rate and effective collection. However such elements are not well articulated in the Tanzanian legal and administrative setting in order to warrant effective property tax performance.

\section{Recommendations}

On the basis of the legal and administrative challenges observed under C. above this paper brings forward a number of recommendations which intends to better administration of property tax in Tanzania. The recommendations address both legal and non-legal challenges which in one way or the other affect property tax administration in the country as presented hereunder:

\section{Ensure full coverage of properties}

Effective administration of property tax is not feasible where there is poor identification of buildings to be subjected to taxation. This calls for the relevant authorities to ensure that buildings in all areas of the country are fully identified for the purpose of taxation failure of which limits its taxation thus low contribution to revenue generation. In order to facilitate this important task availability of accurate and up-to-date property descriptions data is necessary to form part of the entries in the tax roll. Coverage of properties in the tax roll informs on the "what question" aiming at informing on the actual existence of the property, its location, size, condition and topography. This information is highly relevant for determination of property value thus affecting also the rating structure for property tax.

\section{Valuation of the Properties}

The concept of valuation is very important in facilitation of effective property taxation as it provides the real value for which the property is worth thus a determinant of the tax rate for which the property should be charged. Due to its importance valuation should be regularly carried out as opposed to the current practice in which it is not accorded relevant weight. Moreover the same should be conducted while taking into account the following aspects:

\section{a) Valuation as per Real Market Values}

As a necessary component for property taxation valuation enables assessment of the buildings to be subjected to tax. In order to ensure that the assessment is in line with the equity of the tax system of the specific jurisdiction the same should be conducted on the basis of the market value thus correct tax assessment. To improve equity, therefore, Tanzania needs to begin incorporating market value considerations in the valuation methodology in accordance with the original legal intent. Theory and international practice suggest a number of ways to introduce more of a market approach to property valuation. In short, some form of 
locational adjustment must be included in the valuation methodology. Under the current legal framework, this can either be done through refining the flat rating approach which can make adjustments for factors such as location, size and use or through the UARA which provides for a market value approach to be applied in the whole country.

\section{b) Property Valuation Should Be Conducted on a Mass Valuation Basis}

Valuation in Tanzania is conducted through physical visitations by the respective officers as presented under B.I. above. Apart from being expensive and time consuming the process renders delays in updation of property tax rolls. To overcome these problems, it is advised that Tanzania simplifies its valuation system by adopting a mass valuation approach for property taxation purposes. ${ }^{37}$ Mass valuation of properties hereafter MVP is a process of valuing a group of properties in a specific time frame by using common data, standardized methods, and statistical testing. ${ }^{38} \mathrm{MVP}$ is considered more beneficial as it is more equitable, transparent, timely, cost effective and likely to produce more up-to-date values in a manner that is more transparent, cost effective, timely and sustainable than the individual valuation system. ${ }^{39}$ To reduce the lags in the valuation roll and to minimize the costs involved with valuation, Tanzania should also consider adopting a mass valuation approach for property tax purposes.

\section{c) Sustainability of Property Tax Valuation}

As seen under B.I. above the valuation of properties in Tanzania is conducted on an irregular basis in accordance with the need of valuation data of a particular area and time frame. Such irregularity and need based valuation renders lack of valuation data for a particular area and missing data for a certain period of time. Lack of valuation data highly impairs equitable collection of property tax in the country. It is therefore suggested that relevant authorities ensure regular and sustainable valuation exercises in order to take account of the increasing property values in specific time frame. The sustainability of the valuation process in the course of time firmly will assure effective assessment rating and collection of

37 International Association of Assessing Officers (IAA0), Property Assessment Valuation, p. 20, available at https://www.iaao.org/ accessed on September 2020.

38 Tuğba GÜNEŞ and Ümit YILDIZ, Mass Valuation Techniques Used in Land Registry and Cadastre, Modernization Project of Republic of TURKEY, FIG Working week 2015 From the Wisdom of the Ages to the Challenges of the Modern World, available at https://www.fig.net/resources/pro ceedings/fig_proceedings/fig2015/papers/ts04j/TS04J_gunes_yildiz_7501.pdf, accessed on September 2020.

39 Kelly, Roy and Richard Ward, "Property Tax Reform in South Africa: Possible Application of Computer-Assisted Mass Appraisal (CAMA) Techniques", Unpublished Presentation to the Department of Constitutional Development, Government of South Africa based on research funded through USAID Equity and Growth through Economic Research (EAGER) Project and USIS, Pretoria, South Africa, May 1999. 
property tax through establishment of a long term valuation roll. More importantly the valuation roll which serves as a capturing tool for properties subjected to property tax should be subjected to timely and regular maintenance.

It is however important to note that the valuation process requires resources in terms of funding and skilled personnel at the local government level to handle the same. It therefore goes without saying that the sustainability of valuation process should go hand in hand with institutionalization of the activity at the LGA's level together with capacity building programmes to enhance skills development in terms of property tax valuation.

\section{d) Enhancement of Taxpayer Education on Property Tax}

In order to achieve compliance by taxpayers in terms of property tax, education is an essential requirement thereto. By educating the enhancement of taxpayer education on property tax Stakeholder Education is Essential. Tanzania must continue to place priority on this stakeholder education process. Through a combination of in-house and external training efforts, the Government will need to continually focus on ensuring a high degree of public awareness of the property tax reform objectives and procedures. One key for this will be to effectively link the collection of the property tax revenues with the delivery of improved local services.

e) Harmonized relationship between central and local government

Effective collection of property taxes requires constructive working relations between the central government revenue authority and the Local Government Authorities who act as an intermediary between the central government and the grass root level. Close working relationship between the LGA's and the TRA is equally important at this period of time where the duty to administer property tax has been endowed with the revenue authority. Therefore in order to facilitate ease of administration in terms of data sharing, registration and location involvement of the LGA's is imperative.

\section{REFERENCES}

\section{Statutes}

Township Ordinance, Cap. 101 of 1920

Municipalities Ordinance, Cap 105 of 1946

Local Government (Rating) Ordinance, Cap 317 of 1952

Land Rent and Service Charge Act No. 19 of 1974

Land Act Act No. 4 of 1999

Local Government Finance Act No. 9 of 1982. 
Tax Administration Act No. 10 of 2015

Urban Authorities (Rating) Act Cap 289 of 2010 as revised in 2019

Local Government Authorities (Rating) (Collection of Property Rates), Regulations, Government Notice No.1, Published on 03/1/2020

\section{Journal Articles}

Franzsen, R. and W.H.A Olima 2003, Property Tax Issues in Southern and East Africa: Lessons from South Africa and Kenya, Journal of Property Tax Assessment and Administration, Vol. 8(1), pp.1 18

Giulia Mascagni and Fabrizio Santoro 2018, What is the Role of Taxpayer Education in Africa?, ICTD African Tax Administration Paper 1, Institute of Development Studies, pp.1 - 26

Hidaya Kayuza (2006) Real Property Taxation in Tanzania: Reflections from Dar es salaam City, Utafiti, Vol 7, No. 1, pp. 40-52

Kelly, Roy and Richard Ward, "Property Tax Reform in South Africa: Possible Application of Computer-Assisted Mass Appraisal (CAMA) Techniques", Unpublished Presentation to the Department of Constitutional Development, Government of South Africa based on research funded through USAID Equity and Growth through Economic Research (EAGER) Project and USIS, Pretoria, South Africa, May 1999.

Konyimbih, T. M. 2002 Property Taxation in Tropical Africa: Policy and Strategy in three East African Countries, Journal of Property Tax Assessment and Administration, Vol. 7(1), pp.1 - 18

Mack, N., Woodsong, C.,et al (2005) Qualitative Research Methods: A Data Collectors Field Guide, North Carolina, Family Health International

Tuğba GÜNEŞ and Ümit YILDIZ, Mass Valuation Techniques Used in Land Registry and Cadastre, Modernization Project of Republic of TURKEY, FIG Working week 2015 From the Wisdom of the Ages to the Challenges of the Modern World, available at https://www.fig.net/resources/proceedin gs/fig_proceedings/fig2015/papers/ts04j/TS04J_gunes_yildiz_7501.pdf, accessed on September 2020

\section{Website Information}

Internal Revenue Service. "1.14.4 Personal Property Management" available at https://www.irs.gov/ir m/part1/irm_01-014-004 Accessed on September 2020

International Association of Assessing Officers (IAA0), Property Assessment Valuation, available at https://www.iaao.org/

Tanzania Revenue Authority Website, available at https://www.tra.go.tz 